\title{
Moderná učebnica ruštiny pre samoukov
}

ŠAJGALÍKOVÁ, H., POSOKHIN, I., GROMINOVÁ, A.: Ruština pre samoukov a jazykové kurzy. Bratislava: Aktuell, 2018.

Zvýšený záujem o ruský jazyk a jeho štúdium v posledných rokoch prináša so sebou nové výzvy nielen v oblasti samotného procesu výučby ruštiny ako cudzieho jazyka, no i v príprave a vydávaní nových učebných materiálov, ktoré by svojou kvalitou odpovedali požiadavkám moderného jazykového vzdelávania. Dnešná doba so sebou prináša trend samostatného učenia sa cudziemu jazyku bez pomoci pedagóga. Vzniká tak situácia, kedy sa človek chce naučit nový cudzí jazyk, v tomto prípade ruský, no $\mathrm{z}$ istých dôvodov (finančných, časových, vlastnej viery v svoje schopnosti atd'.) sa rozhodne pre samoštúdium. Na sklonku roka 2018 vydaná učebnica Ruština pre samoukov a jazykové kurzy trojice autorov - Heleny Šajgalíkovej, Ivana Posokhina a Andrey Grominovej - je určená najmä takémuto typu „študenta“, ktorý má často vysokú motiváciu učit’ sa a ochotu dobrovolne venovat’ čas získavaniu nových vedomostí.

Do výslednej podoby učebnice boli zapracované požiadavky poslucháčov kurzov ruštiny, osobné i pedagogické skúsenosti z praxe autorov, ktorí sa dlhodobo venujú didaktike ruského jazyka v školskom prostredí a sú oboznámení s aktuálnymi problémami a t’ažkost’ami študentov pri nadobúdaní vedomostí z jednotlivých oblastí cudzieho jazyka. Učebnicu tak možno zároveň považovat’ za odpoved' autorov na aktuálne problémy jazykového vzdelávania, vdaka čomu - ako uvádza anotácia učebnice na webovom portáli Martinus.sk - „[...] splňa náročné kritériá spoločného európskeho referenčného rámca pre jazyky, európskeho štandardu, ktorý roky precizovali odborníci Európskej únie v oblasti výučby a osvojovania si jazykov a využíva najmodernejšie poznatky didaktiky samoštúdia a sebahodnotenia." [Kniha... 2020]

Ako uvádzajú autori, „[...] svojím aktuálnym zameraním sa učebnica líši od tradičnej obsahovej skladby učebníc na knižnom trhu. " [ŠAJGALÍKOVÁ, POSOKHIN, GROMINOVÁ 2018, 3] Tradičnú obsahovú skladbu predstavuje z ich pohladu často nudnejšia gramatická čast’ učebníc, preto je v danej učebnici obmedzená na nevyhnutné minimum. Samouk má pochopit’ a zvládnut’ gramatické javy v kontexte precízne vypracovaných cvičení.

Po obsahovej stránke je učebnica rozdelená do pätnástich kapitol zameraných na tematické okruhy, ktoré zodpovedajú aktuálnym požiadavkám komunikačnej praxe v oblasti ako profesijného, tak i osobného života. Cielene je zvýšená náročnost' i dĺžka jednotlivých kapitol. Pre učebnicu, ktorá je určená najmä pre samoukov, ide o vítaný prvok, ktorý si síce vyžaduje dlhší čas na štúdium, no, ako dodávajú autori, pokial' 
"[...] chcete rýchlo zvládnut vyše dvetisíc slov a slovných spojení spolu s gramatikou, nič iné vám neostáva." [ŠAJGALÍKOVÁ, POSOKHIN, GROMINOVÁ 2018, 3] Cvičné dialógy i modelové situácie verne reflektujú súčasné rusky hovoriace prostredie. Velmi aktuálne sú aj ukážky správneho zostavenia životopisu či objednávky. Hoci je pomoc učitela najmä pri kontrole správneho vypracovania zadaní neocenitelná, správne riešenie úloh a cvičení je možné overit si aj samostatne pomocou klúča, ktorý sa nachádza na konci učebnice. Nespornou výhodou, a zároveň súčastou učebnice sú dve CD s dialógmi a frázami, ktoré umožňujú samoukovi v domácich podmienkach počut hovorenú ruskú reč a pripravit sa na komunikáciu v ruštine s rodenými hovoriacimi. K rýchlemu osvojeniu ruštiny má pomôct̉ rozsiahla slovná zásoba, slovné spojenia i celé vetné konštrukcie zasadené do konkrétnych situácií. Študent - samouk tak získa povedomie o tom, aký význam nadobúdajú slová v kontexte, čím sa do budúcna eliminuje možnost' ich nesprávneho použitia.

Záverom možno konštatovat', že sa autorom podarilo zostavit skutočne moderne koncipovanú učebnicu reagujúcu na aktuálne požiadavky jazykového vzdelávania, ktorá umožňuje študentovi dosiahnut komunikačnú kompetentnosť vyžadovanú v praxi a svojím obsahovým spracovaním má čo ponúknut aj kurzom ruského jazyka, žiakom či študentom základných i stredných škôl. Učebnica nie je autormi prezentovaná ako prostriedok, zakúpením ktorého sa človek automaticky naučí ruštinu, ale ako užitočný sprievodca na ceste $\mathrm{k}$ osvojovaniu si poznatkov $\mathrm{z}$ ruského jazyka. Deklarované dosiahnutie jazykovej úrovne B1 nie je nemožné vzhladom na prepracovanost̉ i náročnost’ učebnice, no vyžaduje si tak, ako pri štúdiu každého jazyka, zo strany študenta čas, vytrvalost’ a ochotu učit sa pravidelne.

Igor Cintula

\section{Bibliografie:}

Kniha: Ruština pre samoukov a pre jazykové kurzy $+2 C D$ (Helena Šajgalíková, Ivan Posokhin a Andrea Grominová) / Martinus. (2020). <https://www.martinus.sk/?uItem= 441007\&gclid=CjwKCAjwz6_8BRBkEiwA3po2VYSm6IL9TFuh4_ErDYHm3aRJhC7V VfXNuGv33kxDA6s6HPyUeC331WRoChJ8QAvD_BwE>. [online.] [cit. 17. 10. 2020].

ŠAJGALÍKOVÁ, H., POSOKHIN, I., GROMINOVÁ, A. (2018): Ruština pre samoukov a jazykové kurzy. Bratislava. 